\title{
Electrical resistivity methods for landfill monitoring
}

\author{
ŁUKASZ ZAWADZKI ${ }^{1}$, DOROTA WYCHOWANIAK ${ }^{2}$, MARIUSZ LECH ${ }^{3}$ \\ ${ }^{1}$ GEOTEKO Serwis Sp. z o.o., Warsaw, Poland \\ ${ }^{2}$ CERTBUD Sp. z o.o., Warsaw, Poland \\ ${ }^{3}$ Faculty of Civil and Environmental Engineering, Warsaw University of Life Sciences - SGGW, \\ Poland
}

\begin{abstract}
Electrical resistivity methods for landfill monitoring. Every single investment affects the natural environment, and that is why it is so important to eliminate nuisance it could cause. Extremely harmful effect on environment or human health could be expected from waste treatment facilities. One of the kinds of contamination which is a real threat to soil and water environment are leachates from landfills. They contain random chemical composition and can migrate from landfill through soil water flux leading to environmental pollution and degradation of groundwater. This paper focuses on the use of geophysical methods to assess migration of pollutants from the landfill through the subsoil. The laboratory tests of solute transport have been conducted on three soil samples from Łubna site to simulate the contamination flow. Migration of leachates through soil samples was controlled using the column test and electrical resistivity measurements which allow to compare the results obtained with the standard column test method and electrical resistivity measurements. It leads to the conclusion that electrical resistivity methods for contamination transport monitoring in soil-water systems are suitable. Furthermore, field electrical resistivity tomography have been used for monitoring of the vertical sealing system in Łubna landfill.
\end{abstract}

Key words: electrical resistivity method, column test, landfill, leachates

\section{INTRODUCTION}

Municipal landfills are necessary evil that allows to collect waste in a controlled way giving the possibility to mitigate its negative effect on natural environment. Leachates are one of the main by-products from the landfills that need to be dealt with during the landfill exploration and after its closure. Leachates contain random chemical composition and can migrate from landfill through soil water flux leading to environmental pollution and degradation of groundwater.

Monitoring is one of the main tools for reducing the risk of landfill pollution giving the possibility of lead-to-date maintenance. One of the methods that can be used for landfill monitoring is noninvasive electrical resistivity tests that allows to detect leaks, to determine the pollution flow direction and the area of contamination.

Electrical resistivity surveys are indirect methods based on distribution of electrical field in soil. Surveys are typically conducted by the four-pin method based on induction of artificial electrical field in soil between two cur- 
rent electrodes and measurement of voltage difference on pair of potential electrodes (Dahlin 2001). Electrical resistivity methods are widely used for monitoring of landfills and detection of groundwater contamination (Benson et al. 1997, Wilkinson et al. 2010, Samgyu et al. 2016, Aryanti et al. 2017). These methods usually need to be compared with some reference data to prove their applicability for the desired purpose. One of the methods that are used to investigate contamination spread in soil-water systems are tracer tests. In the laboratory conditions column tests are commonly performed (Fetter 2001, Ptak 2004). Column tests are based on forcing the flow of a tracer or tracers through a soil sample in conditions similar to natural and measurements of solution parameters in filtrate on the outflow or outflows from the column (Kietlińska et al. 2004, Dontsova et al. 2006). The combination of electrical resistivity method and tracer test is widely used for characterizing solute transport in soil (Fronczyk et al. 2006). The results of these methods allow to develop suitable flow and contamination transport models for estimating of spatial distribution of contaminants and planning of remediation (Sandberg et al. 2002, Koda et al. 2013).

In this study experiments of solute transport in laboratory scale have been conducted using the column test and electrical resistivity method to simulate contamination flow. Furthermore, the results of field electrical resistivity tomography conducted on Łubna landfill for monitoring of vertical cut-off wall are presented.

\section{TEST SIDE, MATERIAL}

\section{AND METHODS}

The investigation was performed on Łubna municipal landfill located in Baniocha village. The study included monitoring of the vertical cut-off wall of Łubna landfill using field electrical resistivity tomography and simulation of contamination flow on soil samples from Łubna site performed in laboratory conditions. In situ measurements were taken on the south-west side of Łubna landfill, one inside and the other outside the vertical sealing system. Location of investigation area is shown in Figure 1.

Laboratory investigation was performed on three soil samples taken from the vicinity of the landfill (piezometer: 1A - sample S1, 15A - sample S2 and 30 - sample S3). Samples of groundwater were also collected from piezometers S1-S3. Parameters characterizing soil samples have been presented in Table 1 and Figure 2. For each soil the laboratory tests of tracer (chlorides) and leachates transport have been performed. Migration through soil samples was controlled using the column test and electrical resistivity method.

The laboratory stand was set on the Faculty of Civil and Environmental Engineering WULS-SGGW. Tests were performed using a $50 \mathrm{~cm}$ long and $10.5 \mathrm{~cm}$ of inner diameter PVC column equipped with four levels of electrodes (P1, P2, P3, P4 on Fig. 3) arranged in square array (10 cm distance between each electrode level). Measurements levels have been calibrated on various solutions to determine geometric factor $-\mathrm{K}(\mathrm{m})$, which was $K=0.88$ for the used column. 


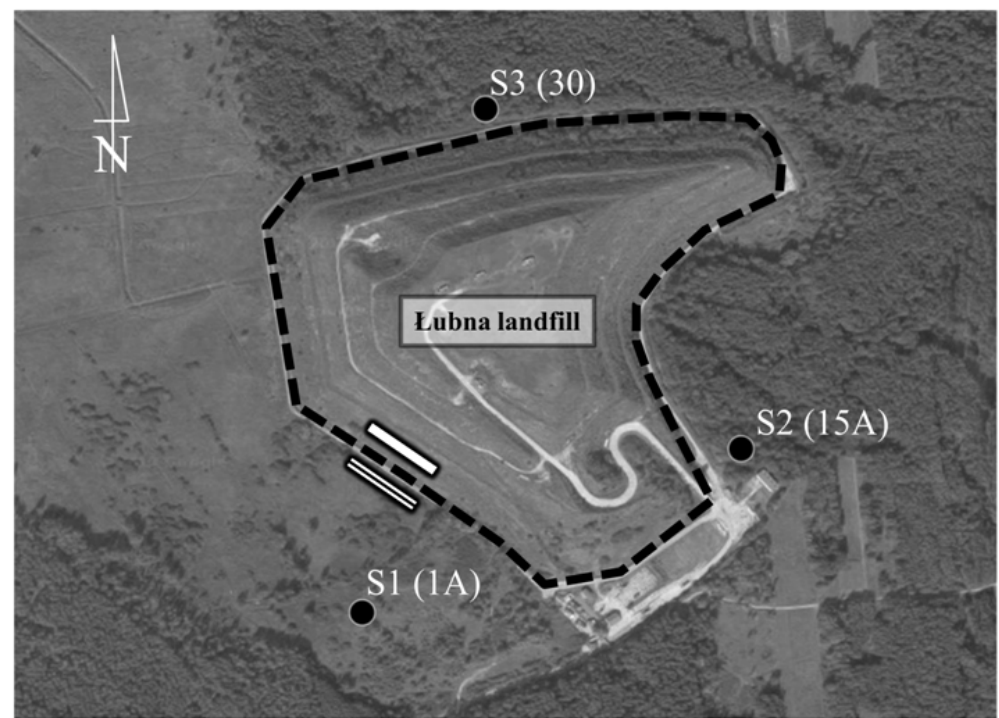

$$
\begin{array}{ll}
\text { - } & \text { - cut-off wall } \\
\hline \text { S1 (1A) } & \text { - electrical resistivity measurement inside the sealing } \\
\text { - soil and water sampling sites }
\end{array}
$$

FIGURE 1. Location of investigation area on Łubna landfill (Google maps 2017)

TABLE 1. Statistics of electrical conductivity calculation from resistivity measurements

\begin{tabular}{|c|c|c|c|c|c|c|}
\hline Sample & Soil type & $I_{D}(-)$ & $n(-)$ & $k(\mathrm{~m} / \mathrm{s})$ & $E C(\mu \mathrm{S} / \mathrm{cm})$ & $\mathrm{pH}(-)$ \\
\hline S1 (1A) & FSa & 0.49 & 0.31 & $5.76 \cdot 10^{-6}$ & 32.30 & 5.36 \\
\hline S2 (15A) & MSa & 0.53 & 0.34 & $2.76 \cdot 10^{-5}$ & 68.90 & 6.60 \\
\hline S3 (30) & MSa & 0.75 & 0.37 & $2.48 \cdot 10^{-5}$ & 54.70 & 6.68 \\
\hline
\end{tabular}

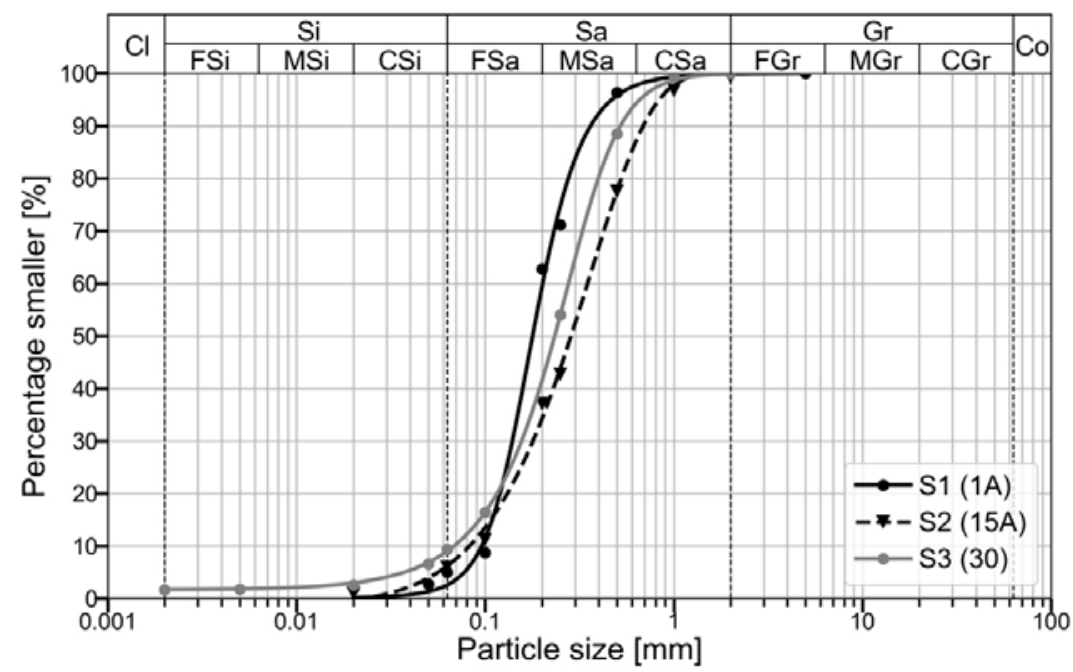

FIGURE 2. Particle size distribution curve of soils from Łubna site 
Before running, the tests samples were formed in $0.05 \mathrm{~m}$ compacted layers and fully saturated with flushing liquid. The flow was forced from bottom to top and solution was injected by pulse method - Dirac function $\delta(t)$ (Wychowaniak et al. 2015). The end of solution injection was followed after reaching the maximum concentration of injected substance in filtrate at the outflow. The tests consisted of four stages including: chlorides flow through soil sample, flushing sample by distilled water, leachates flow and flushing leachates by water from piezometer. During tests the electrical resistivity measurements were taken for each electrode level and the physio-chemical parameters such as: chlorides (tracer transport), conductivity, $\mathrm{pH}$ and temperature have been controlled in water at the outflow from the column. Test setup for contamination transport measurement has been shown in Figure 3.
Electrical properties of soils are mainly controlled by concentration of dissolved substances in water filling its pores, thus electrical resistivity methods can be used for monitoring of groundwater. For interpretation of electrical resistivity measurements mostly empirical Archie's law (Archie 1942) is used. It's relates electrical resistivity of fully saturated soil $-\rho_{g}(\Omega \mathrm{m})$, to porosity $-n(-)$, and resistivity of the liquid in its pores $-\rho_{f}(\Omega \mathrm{m})$. Usually, Archie's law is expressed as the formation factor $(F)$ and expressed as:

$F=\frac{\rho_{g}}{\rho_{f}}=a \cdot n^{-m}$

where:

$a-$ soil tortuosity factor (-);

$m-$ soil cementation exponent (-).
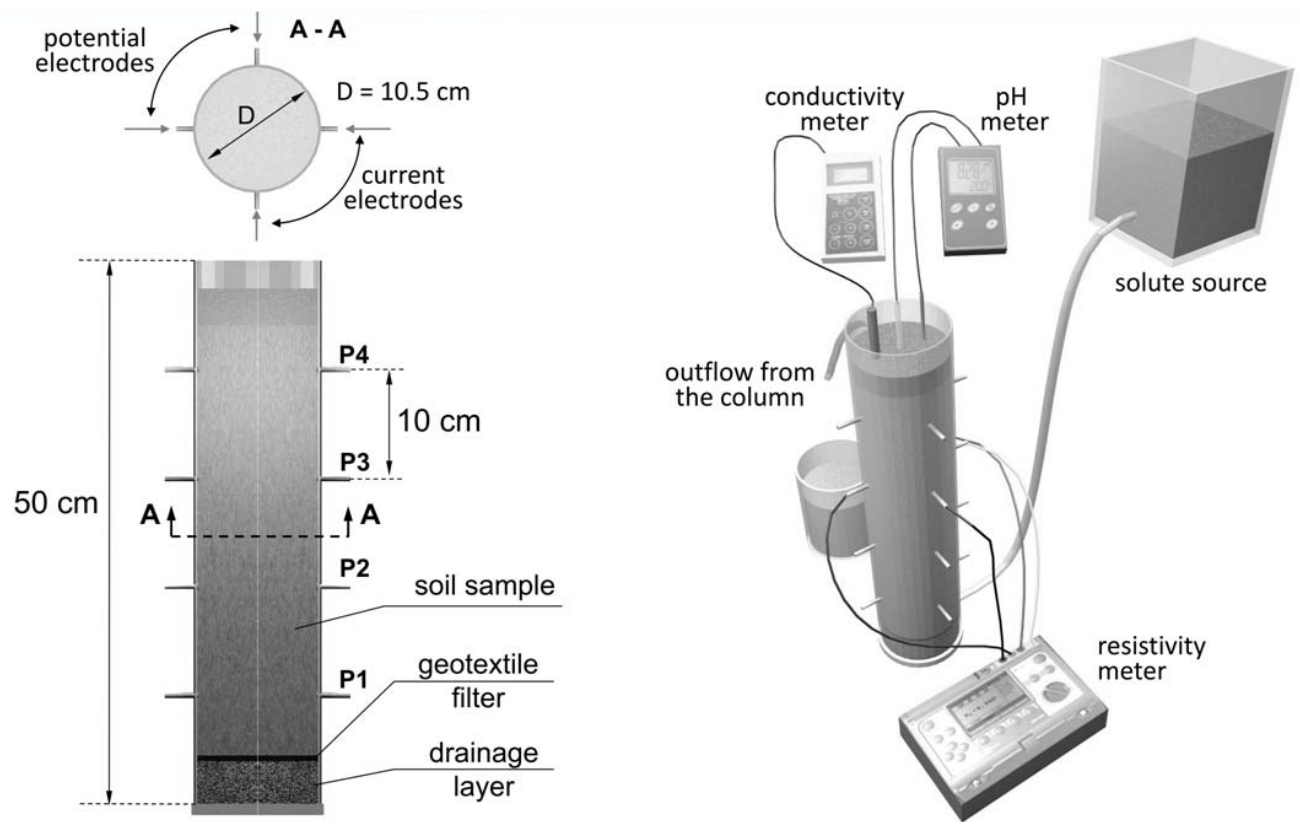

FIGURE 3. The experimental setup for solute transport measurement 
Use of Archie's law usually requires conduction of laboratory calibration tests for determination of model parameters. For simplification usually adaptation of Archie's law for specified soil types are used (Buryakovsky 2012, Zawadzki 2016). For sandy soils simplified model can be expressed as:

$F=n^{-1.5}$

Regarding above assumptions, electrical conductivity of contaminant in sandy soils from electrical resistivity measurements can be calculated from equation:

$\sigma_{\text {calc }}=\frac{F}{\rho_{g}}=\frac{n^{1.5}}{\rho_{g}}$

where:

$\sigma_{\text {calc }}(\mathrm{S} / \mathrm{m})$;

$F(-)$;

$\rho_{g}(\Omega \mathrm{m})$.

a

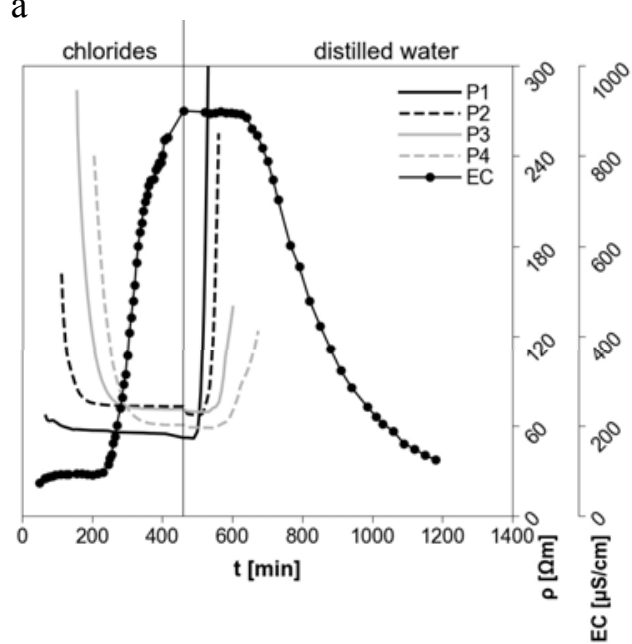

\section{RESULTS AND DISCUSSION}

The results of laboratory electrical conductivity (measured on filtrate on outflow) and resistivity (on four levels P1, P2, P3, P4 notation as in Fig. 3) measurements for the tested samples have been shown in Figures 4, 5 and 6. As concentration of substances dissolved in pore water controls mainly its electrical properties, electrical resistivity measurements mirrors measured breakthrough curves. Electrical conductivity of water contained in soil pores can be calculated from electrical resistivity measurements from equation (3). Comparison between reference values (known water electrical conductivity) and electrical conductivity calculated from resistivity measurements for tests performed in laboratory conditions have been shown in Table 2 . It can be noticed that values of electrical conductivity recalculated from tests performed on chlorides are more accurate than values from leachate tests. This

b

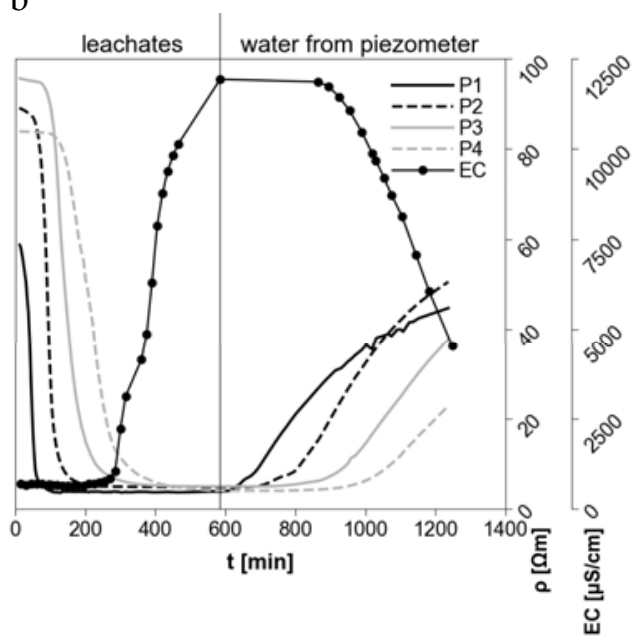

FIGURE 4. Breakthrough curve of conductivity and electrical resistivity in sample S1 (a) chlorides flow; (b) leachates flow 
a

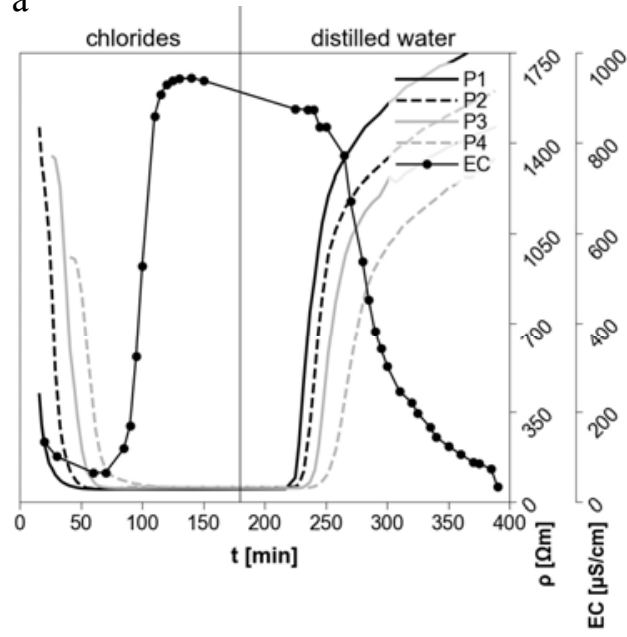

b

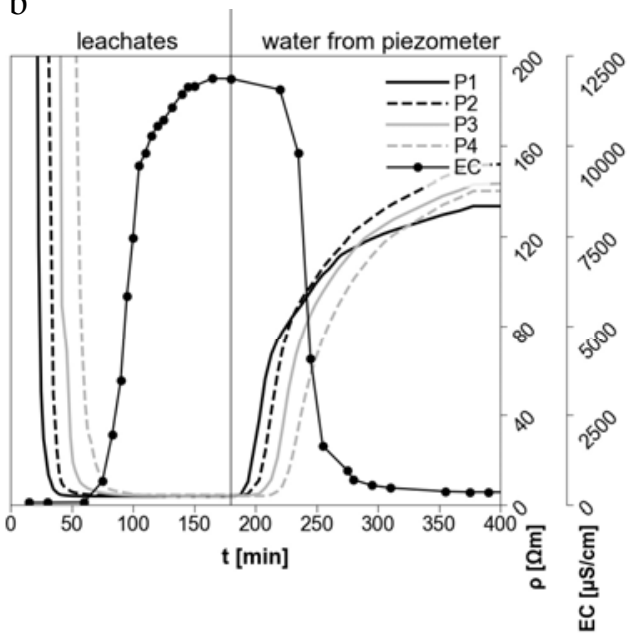

FIGURE 5. Breakthrough curve of conductivity and electrical resistivity in sample S2 (a) chlorides flow; (b) leachates flow

a

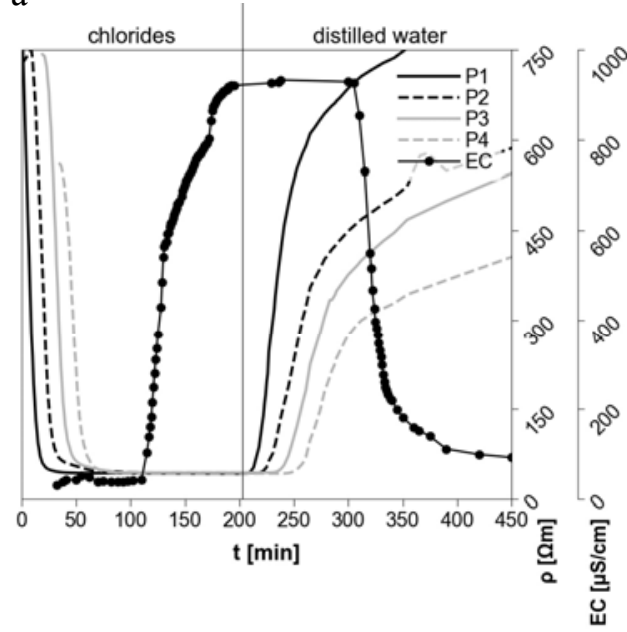

$\mathrm{b}$

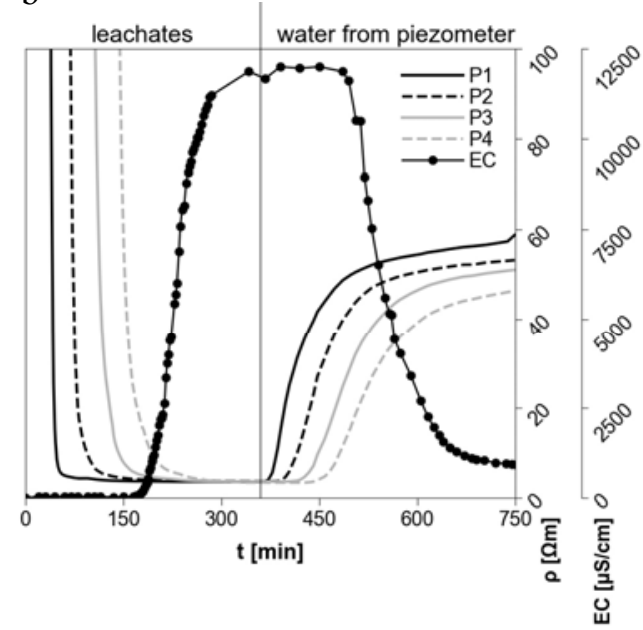

FIGURE 6. Breakthrough curve of conductivity and electrical resistivity in sample S3 (a) chlorides flow; (b) leachates flow

is caused by random and uncontrolled chemical composition of leachates in comparison to chlorides solution consisting of a single compound. It means that accuracy of results is not only controlled by simplifications adopted during the calculation process but also by chemical composition of water in soil pores, i.e. number of different ions in fluid. In laboratory conditions proper calibration can be conducted to increase accuracy, but in field conditions calibration is not possible. Thus, in such conditions calculated values should be treated as estimates. 


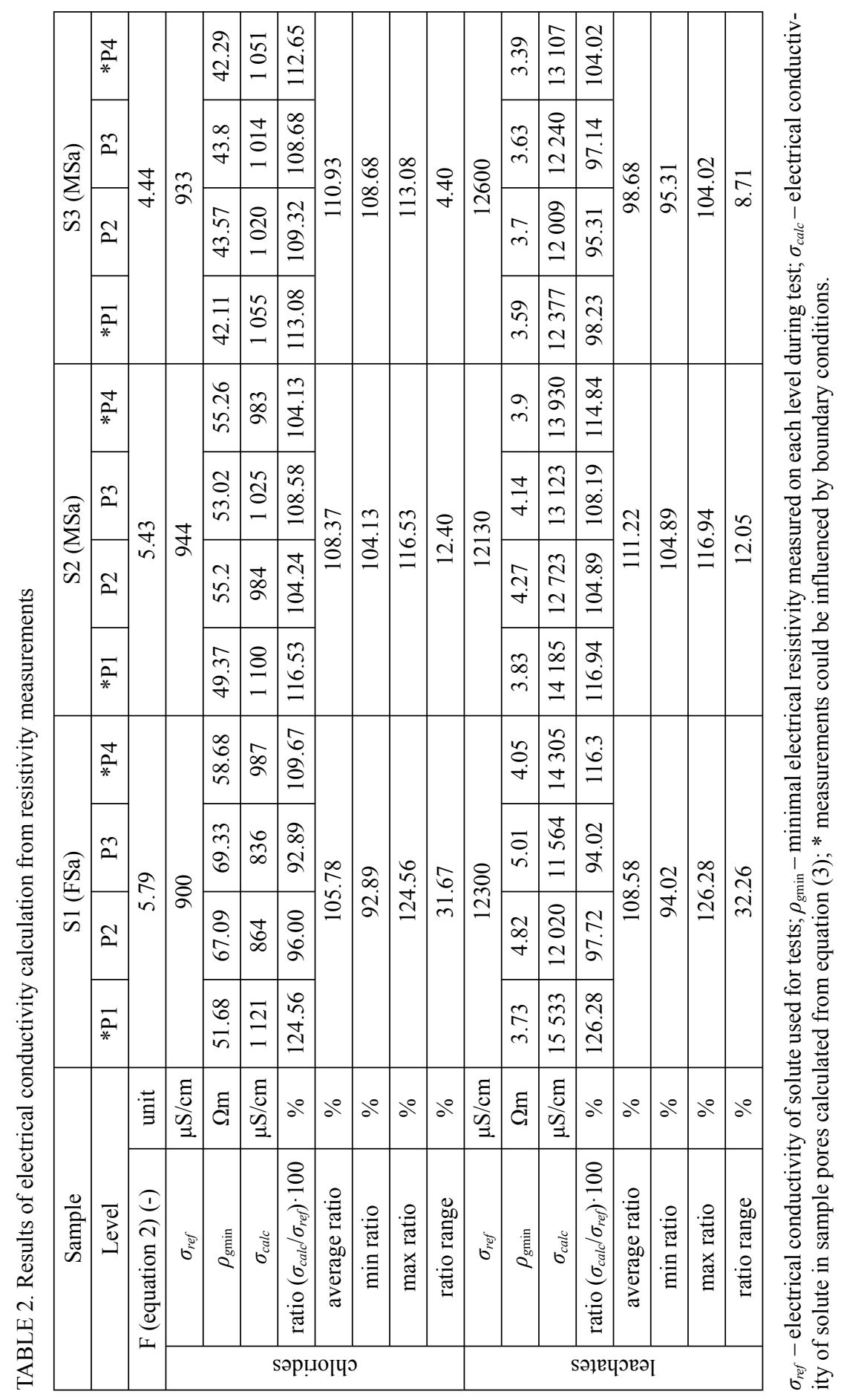


In addition, the hydrodynamic parameters of tracer flow (chlorides) were determined for the first stage of the laboratory investigations. The results of the tests were interpreted using the STANMOD program CXTFIT package (Toride et al. 1995) in order to check their degree of fit into the model and obtain migration parameters such as: flow velocity $\left(v_{a}\right)$, hydrodynamic dispersion coefficient $\left(D_{H}\right)$, longitudinal dispersion $\left(\alpha_{L}\right)$ and Péclet number (Pe). Table 3 contains the results of calculations of contaminant migration parameters estimated on the basis of tests.

The values of $D_{H}$ and $v_{a}$ were calculated with determination factors $\left(R^{2}\right)$ from 0.92 to 0.95 . The values of the Péclet number indicate, in accordance with the division of contaminant migration mechanisms presented by i.a. Bear and Cheng (2004), Barbour et al. (2012), transport resulting mainly from the mechanisms of advection and dispersion. In the case of all samples, the determined longitudinal dispersion $\left(\alpha_{L}\right)$ values are within the range of values determined on the basis of the column tests carried out so far, including the following publications: Gelhar et al. (1992), Okońska (2006). The breakthrough curves (Figs. 4-6) for individual samples are characterized by a variable migration rate of the chlorides solution. Chloride ions were the fastest moving in soil sample S2 (15) and slowest in sample S1 (1A).
Apart from laboratory investigations, also in situ resistivity tomography can be a very helpful method in many geoenvironmental problems. Soil and rock minerals are in most cases highly resistive. In this connection, the flow of current is conducted primarily through the pore spaces filled with water so the resistivity of soils is controlled mainly by the porosity, the amount of groundwater in pore spaces and its dissolved solids concentration. In this case this phenomena were used to detect and locate the leachates from waste disposal and to detect potential leaks through the vertical sealing system.

For this purpose, two parallel cross-sections were traced along the cut-off wall - the first was located inside while the other was located outside the vertical sealing system. Figure 7 presents the results of electrical resistivity survey that was carried out on the disposal site of Łubna.

The results for cross-section A (Fig. 7A) carried out inside the vertical sealing system shows, that to the depth of about $12 \mathrm{~m}$ electrical resistivity values are lower than $4 \Omega \mathrm{m}$. This zone is formed by sands and certainly saturated with leachate from the landfill. In the central part of the cross-section and depth of $12 \mathrm{~m}$ below, the electrical resistivity is between 20 and $50 \Omega \mathrm{m}$, and these values do not indicate the presence of contaminants in this area.

TABLE 3. Parameters of chlorides migration

\begin{tabular}{|c|c|c|c|c|c|c|}
\hline Sample & Soil type & $v_{a}(\mathrm{~m} / \mathrm{s})$ & $D_{H}\left(\mathrm{~m}^{2} / \mathrm{s}\right)$ & $\alpha_{L}(\mathrm{~m})$ & $\operatorname{Pe}(-)$ & $R^{2}$ \\
\hline S1 $(1 \mathrm{~A})$ & FSa & $2.11 \cdot 10^{-5}$ & $3.12 \cdot 10^{-7}$ & 0.015 & 27.39 & 0.95 \\
\hline S2 $(15 \mathrm{~A})$ & MSa & $8.72 \cdot 10^{-5}$ & $4.33 \cdot 10^{-6}$ & 0.050 & 27.67 & 0.92 \\
\hline S3 (30) & MSa & $8.18 \cdot 10^{-5}$ & $3.33 \cdot 10^{-6}$ & 0.041 & 10.73 & 0.94 \\
\hline
\end{tabular}

According to Fetter (1999): $\alpha_{L}=D_{H} / v_{a}$ and $\mathrm{Pe}=v_{a} \cdot L / D_{H} ; L-$ the length of the soil sample $(\mathrm{m})$. 
a

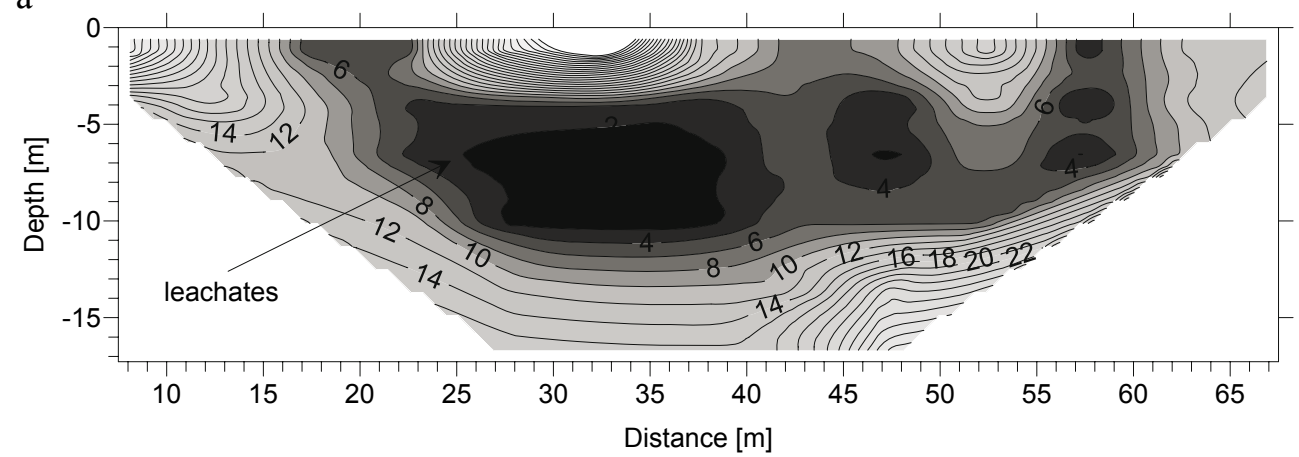

b

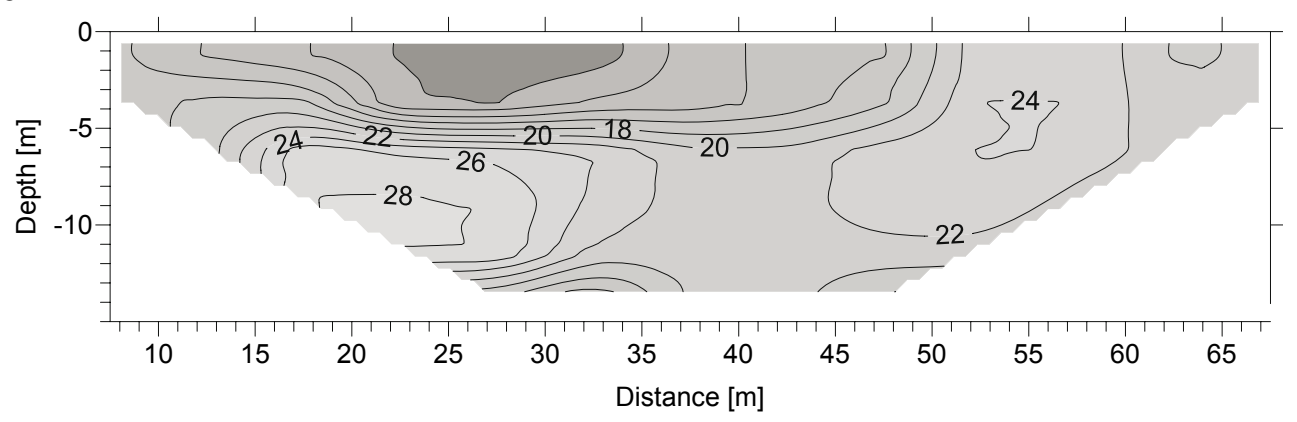

Electrical resistivity [Ohm*m]

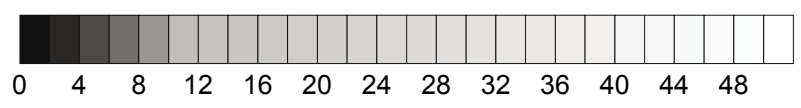

FIGURE 7. The electrical resistivity cross-section inside (A) and outside (B) vertical sealing system

The results of measurements outside of the cut-off wall are shown in section B (Fig. 7B). These studies indicate that the entire cross-section of the ground surface to a depth of approx. $15 \mathrm{~m}$ there are deposits with electrical resistivity in range between 20 to $30 \Omega \mathrm{m}$ representing natural sands that do not indicate the occurrence of landfill leachate.

Furthermore, assuming that the average formation factor of the investigated sands is about 5, the electrical conductivity of pore water can be also estimated. On the basis of field investigations, the electrical conductivity of the leachates was deter- mined between 5,000 and $12,500 \mu \mathrm{S} / \mathrm{cm}$, whereas groundwater outside the cut-off wall between 250 and $500 \mu \mathrm{S} / \mathrm{cm}$. These values confirm the results of laboratory tests, which showed that the electrical conductivity of leachate from Łubna landfill is approximately $12,300 \mu \mathrm{S} / \mathrm{cm}$.

\section{CONCLUSIONS}

The presented study allowed to draw the following conclusions:

1. Electrical resistivity methods can be successfully used for municipal landfill monitoring. Column tests 
performed during research show that calculated electrical conductivity of contaminant differs from reference values about 5 to $10 \%$ (excluding P1 and $\mathrm{P} 4$ influenced by boundary conditions). In field conditions this value can be greater. Obtained values of the Péclet number indicate the contaminant flow resulting mainly from the processes of advection and dispersion.

2. Accuracy of indirect electrical resistivity measurements is controlled by calculation assumptions (e.g. model for calculating of formation factor) and chemical compound of water in soil pores (more different ions mean less accuracy).

3. As electrical resistivity methods are non-invasive, they can be used as first alert system for detection of contaminant leakage from landfill e.g. through vertical cut-off wall.

4. Electrical resistivity methods are sensitive to changes in water chemistry, both as a result of natural and anthropogenic factors which may result in false alarms during monitoring.

5. As electrical resistivity methods are indirect, it is not possible to determine contaminant compound but only change resultant resistance of substance.

6 . The field tests have shown the possibility of assessing the effectiveness of cut-off wall around the landfill (the effectiveness of the cut-off wall on the tested section of the landfill has been confirmed).

7. It is also possible to determine the electrical conductivity of water in pore spaces however, only in the fully saturated conditions.

\section{REFERENCES}

ARCHIE G.E. 1942: The electrical resistivity log as an aid in determining some reservoir characteristics. Trans. AIMME 146: 54-61,

ARYANTI E., PUJI ARDI A., ALMUNZIRI M., YAHD XANGGAM Z., ELEAZAR A., WIDODO 2017: Waste disposal mapping with electrical resistivity tomography case: Leuwigajah landfill. AIP Conference Proceedings 1861, 030053. doi: 10.1063/1.4990940

BARBOUR S.L., HENDRY M.J., WASSENAAR L.I. 2012: In situ experiment to determine advective-diffusive controls on solute transport in a clay-rich aquitard. J. Contam. Hydrol. 131 (1-4): 79-88.

BEAR P.D.J.J., CHENG D.H-D.A. 2010: Modeling Contaminant Transport. Modeling Groundwater Flow and Contaminant Transport. Springer, Netherlands.

BENSON A.K., PAYNE K.L., STUBBEN M.A. 1997: Mapping groundwater contamination using de resistivity and VLF geophysical methods - A case study. Geoph. 62 (1): 80-86,

BURYAKOVSKY L.A. (Ed.) 2012: Petrophysics: fundamentals of the petrophysics of oil and gas reservoirs. Scrivener Pub., Wiley, Beverly, MA, Hoboken, N.J.

DAHLIN T. 2001: The development of DC resistivity imaging techniques. Comp. Geosci. 27: 1019-1029.

DONTSOVA K.M., YOST S.L., SIMUNEK J., PENNINGTON J.C., WILLIFORD C.W. 2006: Dissolution and transport of TNT, RDX, and Composition B in saturated soil columns. J. Environ. Qual. 35 (6): 2043-2054.

FETTER C.W. 1999: Contaminant Hydrogeology. Prentice Hall, Upper Saddle River, NJ.

FETTER C.W. 2001: Applied Hydrogeology. Prentice Hall, Upper Saddle River, NJ.

FRONCZYK J., GARBULEWSKI K., LECH M. 2006: Hydraulic, sorption and resistivity characteristics of zeolite-sand mixture for PRBs. In: $5^{\text {th }}$ ICEG Environmental Geotechnics, 26-30.06.2006. Thomas Telford, London: 140-147.

GELHAR L.W., WELTY C., REHFELDT K.R. 1992: A critical review of data on field-scale dispersion in aquifers. Water Res. Res. 28 (7): 1955-1974. 
KIETLIŃSKA A., RENMAN G., JANNES S. 2004: Landfill leachate treatment for metal removal by filtration through reactive substrates - column experiment. Ann. Warsaw Univ. Life Sci. SGGW, Land Reclam. 35: 89-97.

KODA E., KOŁANKA T., OSIŃSKI P. 2013: Investigation of soil contamination level beneath the metallurgical waste landfill for the purpose of future reclamation works. Ann. Warsaw Univ. Life Sci. SGGW, Land Reclam. 45 (1): 5-16.

OKOŃSKA M. 2006: Identyfikacja parametrów migracji zanieczyszczeń $\mathrm{w}$ porowatym ośrodku hydrogeologicznym metodą modelowania eksperymentu kolumnowego. Bogucki Wydawnictwo Naukowe, Poznań.

PTAK T., PIEPENBRINK M., MARTAC E. 2004: Tracer tests for the investigation of heterogeneous porous media and stochastic model ling of flow and transport - a review of some recent development. J. Hydrol. 249: 122-163.

SAMGYU P., MYEONG-JONG Y., JUNG-HO K., SEUNG WOOK S. 2016: Electrical resistivity imaging (ERI) monitoring for groundwater contamination in an uncontrolled landfill, South Korea. J. Appl. Geoph. doi: 10.1016/j.jappgeo.2016.07.004

SANDBERG S.K., SLATER L.D., VERSTEG R. 2002: A integrated geophysical investigation of hydrogeology of an anisotropic unconfined aquifer. J. Hydrogeol. 267: 227-243.

TORIDE N., LEIJ F.J., Van GENUCHTEN M.Th. 1995: The CXTFIT code for estimating transport parameters from laboratory or field tracer experiments. Research Report 137. U.S. Salinity Laboratory, USDA, ARS, Riverside, CA.

WILKINSON P.B., MELDRUM P.I., KURAS O., CHAMBERS J.E., HOLYOAKE S.J., OGILVY R.D. 2010: High-resolution ERT monitoring of a tracer test in a confined aquifer. J. Appl. Geoph. 70 (4): 268-276.

WYCHOWANIAK D., ZAWADZKI Ł., LECH M. 2015: Application of column tests and electrical resistivity methods for leachate transport monitoring. Ann. Warsaw Univ. Life Sci. SGGW Land Reclam. 47 (3): 237-247.

ZAWADZKI Ł. 2016: Zastosowanie metody elektrooporowej do określania stanu nasycenia wodą gruntów piaszczystych. $\mathrm{PhD}$ thesis, SGGW.
Streszczenie: Zastosowanie metody elektrooporowej do monitoringu sktadowisk odpadów. Każda inwestycja wywiera wpływ na środowisko naturalne, dlatego konieczne jest podejmowanie odpowiednich działań mających na celu zmniejszenie ich negatywnego oddziaływania na środowisko. Jedno z największych zagrożeń dla środowiska i zdrowia ludzi stanowią składowiska odpadów, a w szczególności odcieki będące ich produktem ubocznym. Odcieki charakteryzujące się niekontrolowanym składem chemicznym mogą dostawać się do wody gruntowej, powodując zanieczyszczenie środowiska gruntowo-wodnego. W artykule skupiono się na zastosowaniu metody elektrooporowej do monitoringu składowisk odpadów. $\mathrm{W}$ ramach prac przeprowadzono badania terenowe skuteczności pionowej przesłony izolacyjnej na składowisku Łubna oraz badania laboratoryjne transportu zanieczyszczeń dla trzech próbek gruntu pobranych z badanego składowiska. Pomiary transportu zanieczyszczeń były realizowane z wykorzystaniem badań kolumnowych i metody elektrooporowej.

Stowa kluczowe: metoda elektrooporowa, badanie kolumnowe, składowisko odpadów, odcieki

$M S$ received 13.02.2018

MS accepted 04.06.2018

\section{Authors' addresses:}

Łukasz Zawadzki

GEOTEKO Serwis Sp. z o.o.

ul. Wałbrzyska 14/16, 02-739 Warszawa

Poland

e-mail: lukasz.zawadzki@geoteko.com.pl

Dorota Wychowaniak

CERTBUD Sp. z o.o.

ul. Jastrzębowskiego 22/44, 02-786 Warszawa

Poland

e-mail:wychowaniak@certbud.pl

Mariusz Lech

Katedra Geoinżynieri

Wydział Budownictwa i Inżynierii Środowiska

Szkoła Główna Gospodarstwa Wiejskiego

w Warszawie

ul. Nowoursynowska 166, 02-787 Warszawa

Poland

e-mail: mariusz_lech@sggw.pl 